\title{
MUSIK TARI RENTAK BULIANDI SANGGAR KAMBOJA SMPN 1 RENGAT KABUPATEN INDRAGIRI HULU PROVINSI RIAU (ANALISIS UNSUR MELODI)
}

\author{
Rofiandri Suardi \\ Pascasarjana Pendidikan SeniUniversitas Negeri Semarang \\ acordioner@ymail.com
}

\begin{abstract}
Rentak Bulian Dance became one of the arts that grew and developed in Indragiri Hulu Regency. This dance is taught in communities in Indragiri Hulu Regency, and also in School Extracurricular activities. In Sanggar Kamboja SMPN 1 Rengat, Rentak Bulian dance is taught to students and also learns the music of its accompaniment. In this article, the discussion is more focused on dance music Rentak Bulian. The discussion presented is about one musical element, especially the melody. Teaching Rentak Bulian dance and music, is one of the preservation of the artists to be inherited to the generation of young people competent in the world of art.
\end{abstract}

Key Words: Rentak Bulian, The Music Accompaniment, Melody.

Abstrak: Tari Rentak Bulian menjadi salah satu kesenian yang tumbuh dan berkembang di Kabupaten Indragiri Hulu. Tari ini diajarkan di sanggar-sanggar di Kabupaten Indragiri Hulu, dan juga di kegiatan Ekstrakurikuler Sekolah. Di Sanggar Kamboja SMPN 1 Rengat, tari Rentak Bulian diajarkan kepada siswa/i dan juga mempelajari musik iringannya. Dalam artikel ini, pembahasan lebih difokuskan kepada musik tari Rentak Bulian. Pembahasan yang dipaparkan adalah mengenai salah satu unsur pembentuk musik, yaitu melodi. Pengajaran seni Tari Rentak Bulian dan musik tarinya, merupakan salah satu bentuk pelestarian yang dilakukan seniman untuk diwariskan kepada generasi muda-mudi yang berkompetensi dalam dunia seni.

Kata kunci: Rentak Bulian, Musik Iringan, Melodi.

\section{PENDAHULUAN}

Kebudayaan di Riau ada berbagai macam, ini di karenakan banyaknya sukusuku asli dan pendatang yang ada di Riau, seperti : Suku Akit, Suku Sakai, Suku Bonai, Suku Talang Mamak, Jawa, Batak, Melayu, Minang, Banjar dan lain-lainnya. Dengan beragam suku ini, maka terdapatlah beragam budaya yang ada di Riau. Salah satu daerah di Riau yang memiliki beragam suku ini adalah Kabupaten Indragiri Hulu.

Di Kabupaten Indragiri Hulu, terdapat beragam bentuk kegiatan kesenian dan kebudayaan seperti Begawai, Surat Kapal, Berdah, Bezanji, dan Tari Rentak Bulian. Kesenian Tari Rentak Bulian ini, memiliki hubungan dengan salah satu suku dengan kebudayaan yang primitive dan sebagian masih mendiami daerah pedalaman, yaitu Suku Talang Mamak. Suku Talang Mamak ini merupakan salah satu dari sekian banyak suku terasing yang tersebar di kelompok Proto
Melayu (Melayu tua atau Melayu pertama) yang datang lebih awal di kawasan ini (Simanjuntak, et al, 2012:3).

Suku Talang Mamak memelihara, memanfaatkan dan mewariskan hutan sebagai sumber kehidupan. Hutan dipelihara dengan berbagai ketentuan tentang pemeliharaan dan perlindungan alam. Hal seperti ini dapat terlihat dari banyaknya ungkapan adat seperti adat berladang, adat berburu, mendirikan rumah dan bangunan, membuat dusun, dan adat pengobatan. Hal tersebut membuktikan bahwa mereka memiliki kesadaran yang sangat tinggi terhadap pentingnya sumber kehidupan. Di pertegas oleh Isjoni (2005:20) bahwa suatu hal yang sangat menguntungkan bagi Orang Talang Mamak adalah terdapatnya banyak binatang liar di hutan. Binatangbinatang tersebut mereka buru, hasilnya ada yang digunakan untuk konsumsi rumah tangga dan ada pula untuk dijual. Jenis binatang buruannya ada jenis unggas seperti 
ayam hutan, burung nuri, merak, kakak tua hijau, balam, perkutut, beo, dan banyak jenis unggas lainnya. Di samping itu masyarakat juga memburu kijang, harimau, dan sebagainya.

Pada kehidupan masyarakat Suku Talang Mamak terdapat berbagai jenis upacara adat istiadat dan seni budaya yang harus dijaga dan dilestarikan, seperti Bulian Pengobatan, Bulian Tolak Bala, Balai Terbang, Begawai,Tari Rentak Bulian dan masih banyak lainnya. Salah satu kesenian yang berkembang dan terus dilestarikan di Kabupaten Indragiri Hulu adalah Tari Rentak Bulian.

Tari Rentak Bulian merupakan seni tari yang bernuansa magis dan mistis dalam pertunjukkannya. Rentak Bulian merupakan ritual pengobatan, bisa diartikan Rentak adalah melangkah dan Bulian adalah tempat singgah makhluk halus. Tari Rentak Bulian ini dipimpin oleh seorang Kumantan (dukun), diiringi oleh perawan dara cantik serta molek yang membawakan mayang pinang dan wadah yang berisi kemenyan.Tari ini menggunakan mayang pinang sebagai salah satu syarat untuk perlengkapan upacara pengusiran roh jahat dan ritual penyembuhan, ditambah dengan wadah yang berisi pembakaran kemenyan sehingga menimbulkan asap dan memiliki bau yang menambah suasana magis dan mistis.

Kardinal (Buyung) sebagai pelaku seni Tari Rentak Bulian (wawancara Maret 2016), mengungkapkan bahwa tarian ini mampu menarik minat wisatawan lokal dan internasional untuk melihat pertunjukkan tari ini, hal ini dapat dibuktikan dengan penampilan-penampilan Tari Rentak Bulian ini di berbagai kota dan negara, seperti Jepang, Korea, Malaysia, Bandung, Jakarta, Yogyakarta, Tanjung Pinang dan juga daerah yang ada di Riau.

Tarian ini diiringi dengan berbagai alat musik untuk pendukung dalam pertunjukkannya, yaitu gong (dari besi logam untuk pengatur ritme), suling (alat tiup bambu), gendang (alat musik perkusi untuk warna bunyi middle), ketok-ketok (bongkahan batang kelapa yang dilubangi menyerupai kentungan), tambur (gendang berukuran besar sebagai bass dari perkusi).
Tari Rentak Bulian tumbuh dan berkembang di daerah Kabupaten Indragiri Hulu, diajarkan di sanggar-sanggar dan sekolah. Pentingnya mempelajari dan memahami seni dan budaya ini yaitu sebagai wujud apresiasi dan pelestarian kesenian yang ada di daerah sendiri. SMP Negeri 1 Rengat memiliki sanggar sekolah yaitu Sanggar Kamboja, merupakan salah satu sekolah yang melestarikan seni tari Rentak Bulian ini dan juga tari tradisi dan kreasi lainnya, serta mempelajari musik tarinya.

Sanggar Seni Kamboja, merupakan sanggar sekolah binaan SMP Negeri 1 Rengat, Kecamatan Rengat, Kabupaten Indragiri Hulu, Provinsi Riau, mempelajari beragam jenis seni seperti tari, teater, dan musik, tidak terkecuali juga mempelajari musik Tari Rentak Bulian. Penampilan musik dan tari ini biasanya dilaksanakan pada kegiatan-kegiatan besar dan acara-acara di sekolah-sekolah di Kabupaten Indragiri Hulu, dengan durasi penampilan sekitar 7 sampai 8 menit. Romy Alatas selaku tenaga pengajar di Sanggar Kamboja (wawancara Maret 2016) mengungkapkan alat musik yang digunakan dalam musik Tari Rentak Bulian di Sanggar Kamboja SMP Negeri 1 Rengat ini adalah ketok-ketok, gong, tambur, suling, dan gendang.

Musik Tari Rentak Bulian ini tergolong dalam jenis tekstur musik homophonic yaitu hanya berpusat kepada satu melodi utama yang menonjol dengan instrumen lain yang berperan sebagai pengiring atau iringan. Dalam karya ini suling menjadi melodi utama dan diiringi oleh ketok-ketok, gong, tambur dan gendang. Musik ini dimainkan dengan nada dasar tergantung dari suling yang digunakan, pada pembahasan saat ini nada yang digunakan adalah tanda mula Natural $(\mathrm{C}=$ Do atau $\mathrm{A}=\mathrm{La})$ dan karya ini secara keseluruhan menggunakan tanda sukat $\frac{4}{4}$.

\section{PEMBAHASAN Musik}

Menurut pendapat yang dikemukakan oleh M. Suharto (1978: 82) dalam buku Belajar Notasi Balok: "musik adalah suatu pengungkapan gagasan melalui bunyi yang unsur dasarnya berupa melodi, irama serta harmoni dengan pendukung berupa bentuk gagasan, sifat dan warna bunyi”. Jadi, 
membuat sebuah musik dibutuhkan kemampuan menyusun (mengkomposisikan) nada yang mengandung irama, bunyi, dan harmoni.

\section{Analisis Musik}

Menganalisis musik berarti menguraikan komponen-komponen pembentuk musik tersebut. Komponen di sini bisa diartikan sebagai unsur pembentuk musik. Aaron Coplan (1939:33) mengungkapkan bahwa "unsur-unsur musik meliputi: melodi, ritme, harmoni, dan timbre (warna bunyi)". Seperti yang dikemukakan Bruno Nettle dalam bukunya Theory and Methode in Etnomusicologi (1964:98) mentranskripsikan "unsur-unsur musik pada dasarnya adalah mengalihkan unsur-unsur tersebut dari bentuk audio ke dalam bentuk visual atau tulisan". Hal ini sejalan dengan pengertian penotasian dalam etnomusikologi, yaitu "proses mengalihkan bunyi menjadi simbol visual". Tata kerja transkripsi dua cara pendekatan yang penting, yaitu membuat analisa serta mendeskripsikan apa yang kita dengar dan menuliskannya di atas kertas (tentang musik yang didengar) dan mendeskripsikan apa yang kita lihat.

\section{Unsur-Unsur Musik}

Menurut Aaron Copland dalam bukunya What to Listen for in Music (1939:33) dijelaskan dalam Bahasa Indonesia diartikan "unsur-unsur utama yang membentuk musik terbagi empat yaitu ritme, melodi, harmoni dan timbre (warna bunyi)". Ritme memang tidak terlepas dari unsur dasar musik, bahkan dalam sejarah musik, ritme merupakan unsur yang pertama ditemukan dan merupakan unsur tertua dalam unsur musik. Dalam musik Tari Rentak Bulian ini, masing-masing alat musik dimainkan sesuai dengan ritme yang telah ditentukan sebagai salah satu unsur utama musik.

Melodi merupakan salah satu unsur terpenting musik. Joseph Machlis di dalam bukunya The Enjoyment Of Music (1984:7) dalam Bahasa Indonesia "melodi merupakan unsur musik yang membuat daya tarik terbesar dan yang paling menonjol dalam suatu karya musik". Melodi adalah jiwa dari suatu musik, sebagaimana Joseph Machlis (1984:7) menjelaskan bahwa "melodi disebut sebagai jiwa dari musik, kita tahu melodi yang bagus ketika kita mendengar dan kita menyadari kekuatan yang unik untuk menggerakkan kita, sulit untuk menjelaskan kekuatannya. Melodi merupakan unsur musik yang membuat daya tarik terbesar dan yang paling menonjol dalam suatu karya musik". Dari kutipan tersebut, dapat diambil kesimpulan bahwa peranan sebuah melodi sangat menentukan kualitas, daya tarik, pengaruh dan lain sebagainya dalam sebuah karya musik, baik dalam musik, maupun musik tari. Contohnya di dalam alunan melodi musik Tari Rentak Bulian, terdapat alunan suara suling yang begitu khas, sebagai salah satu unsur utama musik. Pada pembahasan ini, unsur yang dibahas adalah hanya unsur melodinya saja.

Harmoni adalah rangkaian nada-nada yang memiliki jarak atau interval. Harmoni yang terdiri dari dua nada atau lebih yang dibunyikan secara bersamaan disebut dengan akor. Musik Tari Rentak Bulian di SMP Negeri 1 Rengat ini, hanya menggunakan satu instrument melodies, yaitu suling bambu, sehingga hanya memiliki harmoni horizontal (pergerakan interval arah ke samping), tidak memiliki harmoni vertikal (arah ke atas / susunan akor)

Timbre atau warna bunyi adalah bunyi atau suara yang dihasilkan oleh setiap alat musik, walaupun nada yang dimainkan sama, tetapi bunyi atau suara yang dihasilkan akan berbeda. Musik Tari Rentak Bulian di SMP Negeri 1 Rengat ini tidak terlepas dari timbre (warna bunyi) yang ada di dalam musik ini. Pada musik ini ada beberapa warna bunyi pada alat musik yang dimainkan.

Berdasarkan penjabaran dari unsur musik menurut Aaron Copland, penulis hanya membahas tentang unsur melodinya saja, yang berkaitan dengan kontur melodi dan intervalnya. Sedangkan unsur lainnya dilampirkan dalam bentuk Partitur Musik Tari Rentak Bulian, dengan susunan yang sesuai pada urutan musik dan susunan alat musiknya.

\section{Unsur Melodi Musik Tari Rentak Bulian}

Pada Musik Tari Rentak Bulian di SMP Negeri 1 Rengat ini, penulis menemukan 4 bagian pokok yang disusun secara berulang dan sistematis sehingga dengan mudah dipahami, yaitu intro, tema 1 , tema 2 , dan transisi. Adapun susunan bagian-bagian pokok berurutan pada struktur komposisi 
Rofiandri Suardi

MUSIK TARI RENTAK BULIANDI SANGGAR KAMBOJA

SMPN 1 RENGAT KABUPATEN INDRAGIRI HULU PROVINSI RIAU (ANALISIS UNSUR MELODI)

musik tari Rentak Bulian ini adalah intro, tema 1 , intro, tema 2 , transisi, intro, transisi, intro, tema 2 , intro dan tema 2.

\section{a. Intro}

Intro atau musik pembuka merupakan musik yang memiliki fungsi sebagai pembuka musik di bagian awal. Oleh karena itu intro perlu untuk menarik perhatian pendengar, sehingga pendengar akan terkesan mengetahui bahwa pertunjukkan akan dimulai bila medengarkan musik tersebut.

Intro pertama dimainkan oleh 4 instrumen saja yaitu ketok-ketok, gong, tambur dan gendang sebagai tanda awal musik pembuka. Dimainkan hanya sebagai pengatur ritme dan tempo awal dengan menggunakan tempo Allegro (cepat) atau senilai $130 \mathrm{bpm}$ (beat perminute).

Intro kedua dan seterusnya juga dimainkan oleh ketok-ketok, gong, tambur dan gendang. Bagian-bagian intro ini dimainkan untuk perpindahan ke bagian lain seperti bagian tema 1 , bagian tema 2 dan juga bagian transisi. di bawah ini!

Untuk lebih jelasnya perhatikan notasi
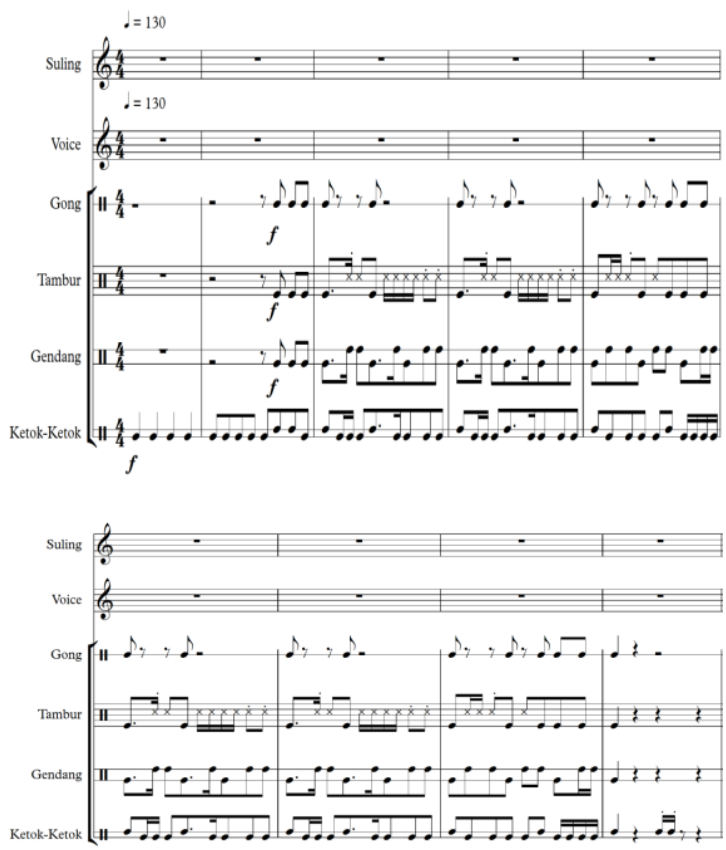

Notasi 1: Cuplikan intro pertama birama

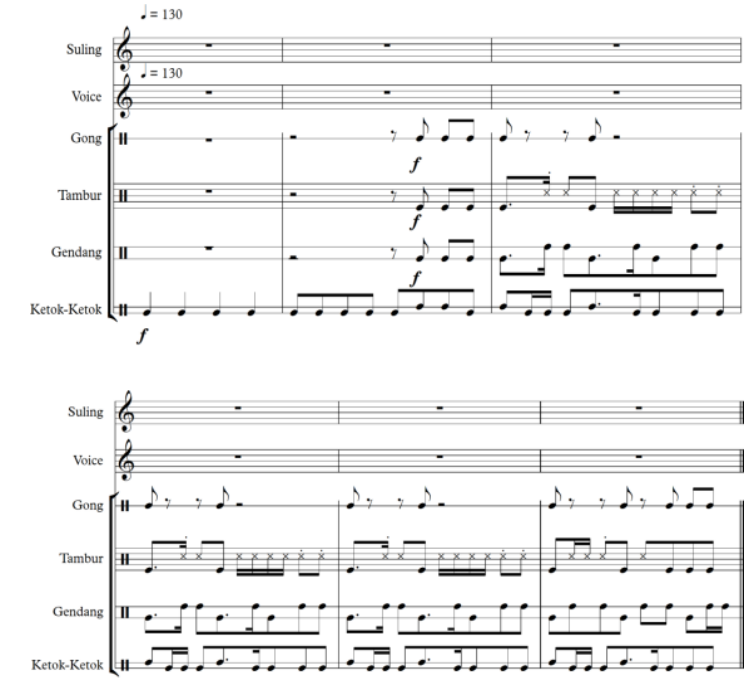

Notasi 2. Cuplikan Intro kedua

Berdasarkan penjelasan bagian intro di atas, penjelasan terkait bentuk struktur melodinya dijelaskan sebagai berikut !

\section{Melodi}

Melodi adalah serangkaian nada yang disusun sedemikian rupa berdasarkan panjang pendeknya nada serta tinggi rendahnya nada yang dibunyikan secara horizontal. Struktur melodi yang akan dijelaskan adalah tentang kontur melodi dan intervalnya.

\section{Kontur Melodi}

Melodi terbentuk dari rangkaian nada. Sebuah melodi yang tetap berada pada nada yang sama akan menjadi bosan dengan cepat. Selama melodi bergerak, nada dari melodi akan bergerak naik dan turun, cepat atau lambat. Dalam istilah musik disebut dengan ascending adalah pergerakan melodi dari nada yang rendah menuju nada yang lebih tinggi dan descending adalah pergerakan melodi dari nada yang tinggi menuju nada yang lebih rendah. Dari pergerakan melodi tersebut, dapat digambarkan dengan sebuah garis yang menanjak terjal ketika melodi melompat ke nada yang jauh lebih tinggi, atau menurun dengan landai ketika melodi perlahan-lahan turun. Garis tersebut menggambarkan kontur atau bentuk dari melodi.

\section{Interval}

Interval adalah jarak antara dua nada. Berikut ini nama-nama interval beserta kualitasnya.

Tabel 1. Nama interval dan kualitas interval 


\begin{tabular}{|l|c|c|c|}
\hline \multicolumn{1}{|c|}{ Nada } & $\begin{array}{c}\text { Jarak } \\
\text { Nada }\end{array}$ & $\begin{array}{c}\text { Nama } \\
\text { Interval }\end{array}$ & Kualitas Interval \\
\hline $\begin{array}{l}\mathrm{C} \rightarrow \mathrm{C} \\
\text { tetap) }\end{array}$ & 0 & Prime & Perfect 1 (P1) \\
\hline $\mathrm{C} \rightarrow \mathrm{D}$ & 1 & Second & Mayor 2 (M2) \\
\hline $\mathrm{C} \rightarrow \mathrm{E}$ & 2 & Terst & Mayor 3 (M3) \\
\hline $\mathrm{C} \rightarrow \mathrm{F}$ & $2 \frac{1}{2}$ & Kwart & Perfect 4 (P4) \\
\hline $\mathrm{C} \rightarrow \mathrm{G}$ & $3 \frac{1}{2}$ & Kwint & Perfect 5 (P5) \\
\hline $\mathrm{C} \rightarrow \mathrm{A}$ & $4 \frac{1}{2}$ & Sekt & Mayor 6 (M6) \\
\hline $\mathrm{C} \rightarrow \mathrm{B}$ & $5 \frac{1}{2}$ & Septim & Mayor 7 (M7) \\
\hline $\begin{array}{l}\mathrm{C} \rightarrow \mathrm{C} \\
(\text { Oktaf) }\end{array}$ & 6 & Oktaf & Perfect 8 (Oktaf) \\
\hline
\end{tabular}

Dari hasil temuan penulis di dalam musik tari Rentak Bulian, pada bagian-bagian intro awal tidak terdapat melodi, karena tidak terdapat pergerakan nada. Ketok-ketok, tambur dan gendang hanya memainkan pola ritme yang diulang-ulang dan gong juga hanya memainkan pola ritme. (Notasi 1). Pada bagian pengulangan intro juga tidak ditemukan melodi, melainkan pengulangan ritme dari gong, tambur, gendang dan ketokketok. (Notasi 2).

\section{b. Tema 1}

Musik tema yaitu musik yang menggambarkan watak atau situasi sesuatu pada bagian musik. Musik jenis ini sering juga digunakan sebagai musik pengenal yaitu musik situasi seperti apa yang digunakan pada bagian-bagian tari.

Tema 1 ini dimainkan oleh semua alat musik, yaitu suling, gong, tambur, gendang dan ketok-ketok, termasuk vokal. Semua alat musik memainkan pola ritme masing-masing, sesuai dengan tempo dan dinamika pada musik tari Rentak Bulian ini.

Perhatikan notasi di bawah ini!

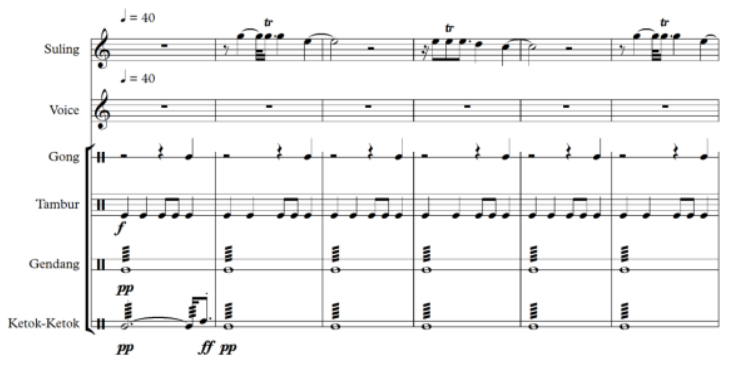

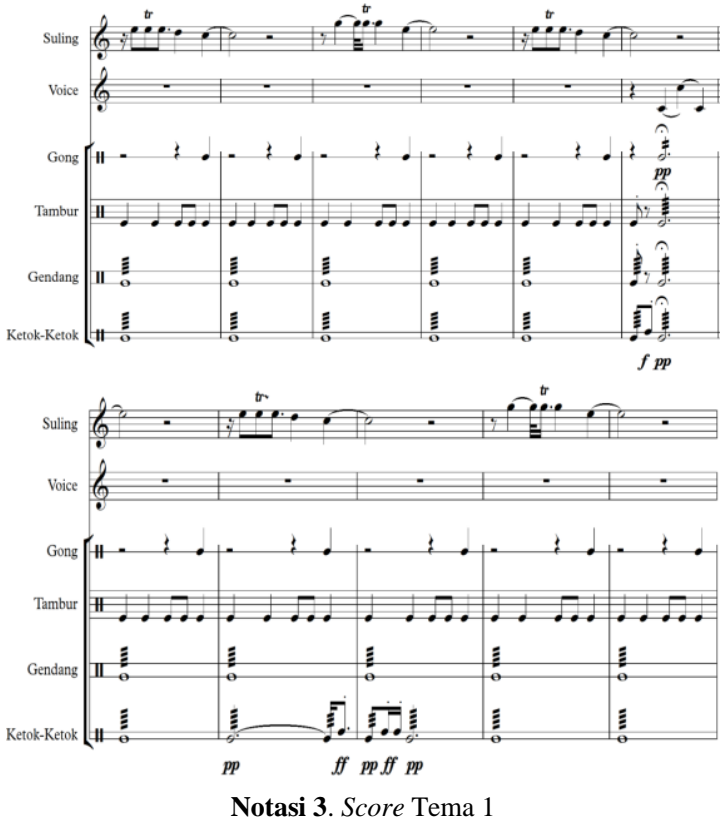

Kontur Melodi

Melodi inti pada tema 1 ini dimainkan dengan berulang-ulang (repetisi). Melodi pada tema 1 ini dimainkan dengan menggunakan instrument musik suling yang termasuk ke dalam kategori Aerophone (sumber bunyi dari udara). Untuk lebih jelasnya, penulis mengambil cuplikan melodi tema 1 ini dari satu kalimat melodi inti saja. Perhatikan kontur melodi di bawah ini!

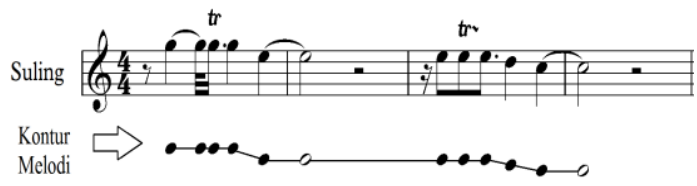

Notasi 4. Melodi inti tema 1.

\section{Interval}

Interval adalah jarak antara dua nada. Berikut ini gambaran interval melodi pada bagian tema 1 beserta kualitasnya. Untuk memperjelasnya, perhatikan notasi di bawah ini!

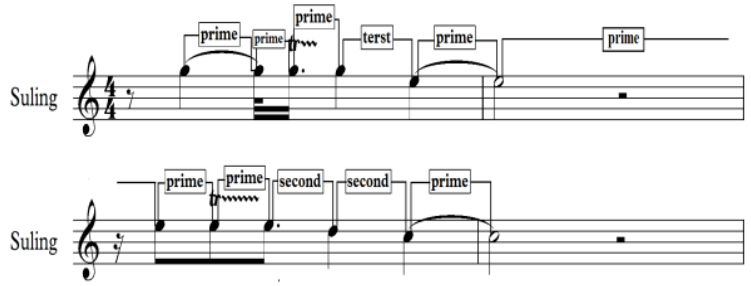

Notasi 5. Interval melodi tema 1. 

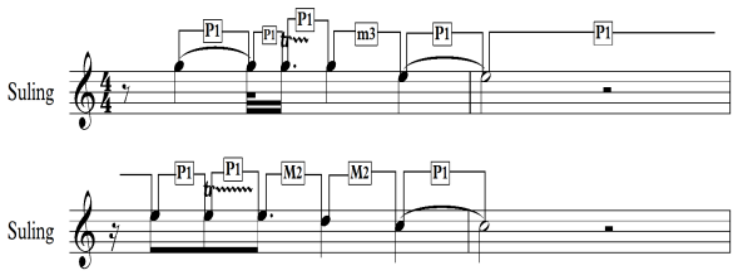

Notasi 6. Kualitas interval melodi tema 1.

Keterangan: Nama-nama interval yang terdapat pada melodi tema 1 ini adalah prime, second dan terst. Sedangkan kualitas intervalnya yaitu P1 (perfect 1), M2 (mayor 2) dan $\mathrm{m} 3$ (minor 3 ).

\section{c. Tema 2}

Memiliki pengertian yang sama dengan tema 1, yaitu sebagai musik tema 2 . Bagian pemecahan dari bagian pokok pada tema 2 ini terdapat 3 bagian.
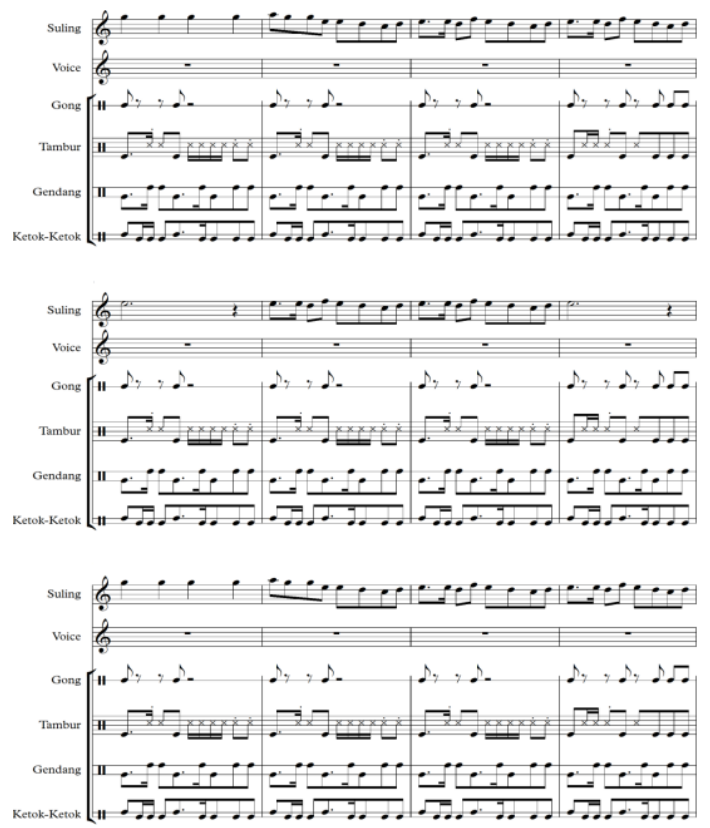

Notasi 7. Cuplikan notasi tema 2

\section{Kontur Melodi}

Melodi pada tema 2 ini dimainkan dengan menggunakan instrument musik suling yang termasuk ke dalam kategori Aerophone (sumber bunyi dari udara). Untuk lebih jelasnya, penulis mengambil cuplikan melodi tema 2 ini dari satu kalimat melodi inti saja. Perhatikan kontur melodi di bawah ini!

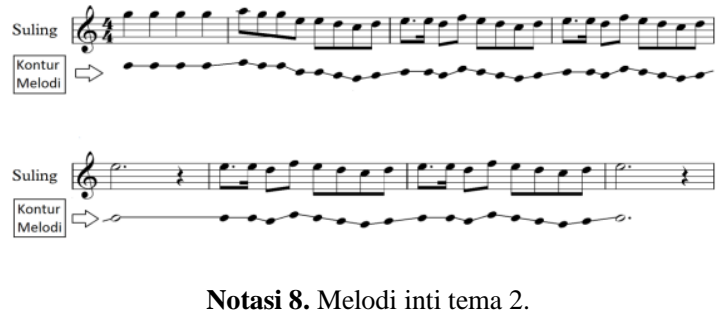

Keterangan: bagian inti melodi dimainkan oleh suling dengan menggunakan gabungan-gabungan not $\frac{1}{2}, \frac{1}{4}, \frac{1}{8}$ dan $\frac{1}{16}$, dimainkan dengan beberapa kali pengulangan (repetisi).

\section{Interval}

Berikut ini gambaran interval melodi pada bagian tema 2 beserta kualitasnya. Untuk memperjelasnya, perhatikan notasi di bawah ini!

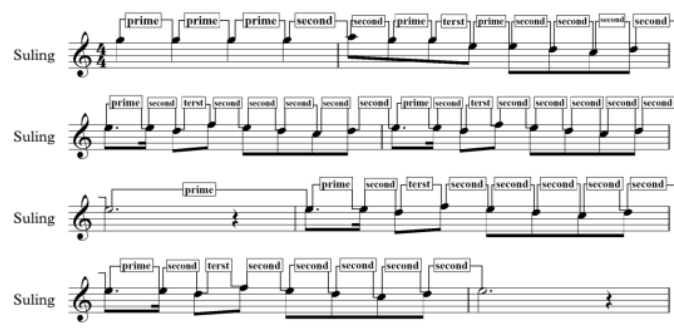

Notasi 9. Interval melodi tema 2

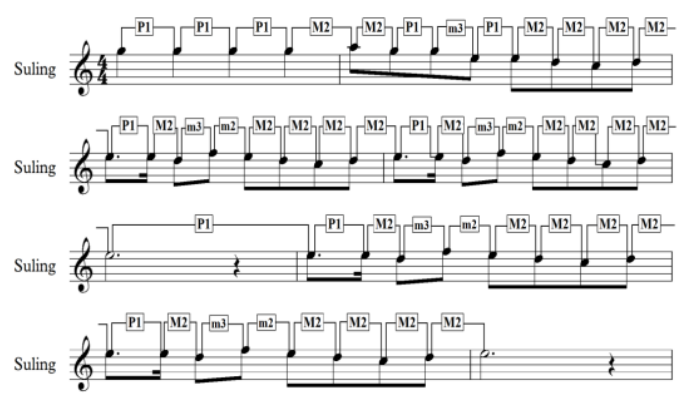

Notasi 10. Kualitas interval melodi tema 2

Keterangan: Nama-nama interval yang terdapat pada melodi tema 2 ini adalah prime, second dan terst. Sedangkan kualitas intervalnya yaitu P1 (perfect 1), M2 (mayor 2), $\mathrm{m} 2$ (minor 2) dan $\mathrm{m} 3$ (minor 3 ).

\section{d. Transisi}

Musik transisi merupakan musik perpindahan. Transisi dimainkan oleh ketokketok, gong, tambur dan gendang. Alat musik tersebut dimainkan dengan pola ritme masingmasing, sesuai dengan tempo dan dinamika pada musik tari Rentak Bulian ini. Untuk lebih jelasnya, perhatikan notasi di bawah ini! 


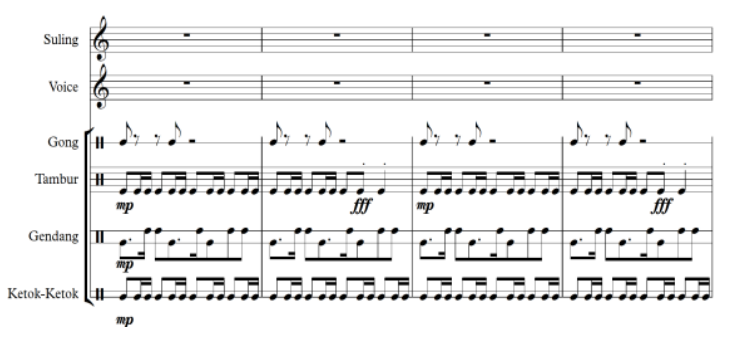

\section{Melodi}

Notasi 11. Cuplikan bagian transisi.

Dari hasil temuan penulis di dalam musik tari Rentak Bulian, pada bagian-bagian transisi tidak terdapat melodi, karena tidak terdapat pergerakan nada. Ketok-ketok, gong, tambur dan gendang hanya memainkan pola ritme yang diulang. (Notasi 11).

\section{PENUTUP}

Kabupaten Indragiri Hulu merupakan salah satu kabupaten di Provinsi Riau yang memiliki ragam kebudayaan yang berasal dari suku-suku yang tersebar. Suku Talang Mamak merupakan salah satu suku pedalaman yang ada di Kabupaten Indragiri Hulu. Dalam suku ini, terdapat upacara pengobatan Bulean yang menjadi ide penciptaan Tari Rentak Bulian, beserta musik pengiringnya.

Tari Rentak Bulian dan musik tarinya, diajarkan di salah satu sanggar sekolah di Kota Rengat, yaitu di Sanggar Kamboja SMP Negeri 1 Rengat. Dari pembahasan mengenai musik tari Rentak Bulian, dapat diketahui unsur melodi dari musiknya. Pembahasan yang dianalisis dari unsur melodi musik Tari Rentak Bulian ini adalah tentang Kontur dan Intervalnya. Tari Rentak Bulian, sudah sepantasnya diajarkan di sekolah-sekolah yang ada di Kabupaten Indragiri Hulu, sebagai bentuk pelestarian terhadap kesenian yang tumbuh dan berkembang sehingga menjadi identitas Kabupaten Indragiri Hulu.

\section{DAFTAR PUSTAKA}

Copland, Aaron. 1939. What to Listen for in Music. MCGraw-Hill Book Company: USA.

Isjoni. 2005. Orang Talak Mamak : Perspektif Antropologi Ekonomi. Pekanbaru: UNRI Press.

Machlis, Joseph. 1984. The Enjoyment Of Music. W. W, Norton Company: New York.
Nettle, Bruno. 1964. Theory and Methode in Etnomusicology. New York: The Free Presca Separation of Machilan Publishing Co, Inc.

Simanjuntak, M. et al. 2012. Budaya Pengobatan Masyarakat Talang Mamak di Kabupaten Indragiri Hulu. Dinas Pemuda Olahraga dan Pariwisata Kabupaten Indragiri Hulu.

Soeharto, M. 1992. Belajar Notasi Balok. Jakarta : PT Gramedia. 